\title{
Leverage and performance: Do size and crisis matter?
}

Albert Danso $^{1}$; Theophilus A. Lartey ${ }^{1}$; Daniel Gyimah ${ }^{2}$; Emmanuel Adu-Ameyaw ${ }^{3}$

Corresponding author: Albert.danso@dmu.ac.uk

\footnotetext{
${ }^{1}$ Leicester Business School, De Montfort University, Leicester, LE1 9BH, UK

${ }^{2}$ University of Aberdeen Business School, Aberdeen AB24 3QY

${ }^{3}$ Liverpool John Moores University, Liverpool, LE3 5UG
} 


\begin{abstract}
Purpose: This paper aims to contribute to the capital structure literature by examining the impact of financial leverage on firm performance and also the extent to which firm size and crisis matter in the leverage-performance relationship.
\end{abstract}

Design/method/approach: Using data from 2403 Indian firms during the period 1995-2014, generating a total of 19,544 firm-year observations, panel econometric methods are employed to test the leverage-performance relationship.

Findings: Drawing insights from agency theory and using Tobin's Q (TQ) as our main measure of performance, we uncover that financial leverage is negatively and significantly related to firm performance. We also observe that the impact of financial leverage on firm performance is lower for smaller firms than larger ones. Finally, we show that the 2007/08 financial crisis had no significant impact on the relationship between financial leverage and firm performance.

Originality/value: The paper provides fresh evidence on the impact of leverage on performance, particularly from the context of India. This study is also among the first studies to examine the role of firm size and financial crisis in the leverage-performance relationship.

JEL classification: G01; G30; G31; G32

Key words: Leverage, firm performance, financial crisis, India

\title{
1. Introduction
}

The impact of leverage on firm performance remains an extensively debated and controversial issue, both among policymakers and researchers ${ }^{4}$. Modigliani and Miller's (1958, 1963) seminal findings on capital structure continue to play a fundamental role in modern investigations. With salient contributions from other empirical studies, additional rationalisations have emerged emphasising different relations between leverage and firm performance. Indeed, for most firms, capital structure plays a vital role in strategic and operational decisions (see: Berger et al., 1997; Anderson et al., 2004). Moreover, leverage

\footnotetext{
${ }^{4}$ See Berger and di Patti (2006), Margaritis and Psillaki (2010) and Weill (2008) for positive impact of leverage on firm performance. For negative impact, see Antoniou et al. (2008), Singla and George (2013) and Vithessonthi, and Tongurai (2015). Connelly et al. (2012) found no relationship between financial leverage and firm performance.
} 
promotes effective monitoring and mitigates managerial opportunism, hence ensuring discipline through lender's rights enforcement (Qian et al., 2015). The belief that high leverage among firms enhances firm revenue caused excessive risk-taking to spiral during the decade preceding the 2007/08 global financial crisis. The crisis loosened macroeconomic and financial structures, resulting in higher operational instability in many advanced and emerging markets.

The interest in this topic underscores several scholarly studies on advanced economies over the last decade; however, there have been few on emerging economies such as India. Several contemporary finance studies on developed economies have focused on examining the effects of the recent global financial crisis on firm performance (e.g. Santos, 2010; Kahle and Stulz, 2013; Bremus and Fratzscher, 2015; Cerutti, 2015) Evidence provided by Vithessonthi and Tongurai (2015a) confirms that the quantity and quality of external finance constricted during the global financial crisis as credit availability was constrained. Dungey and Gajurel (2015) suggest that high leverage levels motivated predominantly through aggressive external borrowing raise the risk level of firms. These significant restrictions ultimately impact adversely on firm growth and performance, especially for emerging markets (Bergman and Hutchison, 2015).

Therefore, in this paper we examine the leverage-performance nexus for an emerging economy, India, by drawing on the agency theory. The findings in this paper suggest that, firstly, leverage has a negative effect on firm performance. This effect is present even after controlling for possible endogeneity and also using an alternative measure of firm performance. Secondly, the adverse effects of leverage on firm performance are higher for larger firms than smaller firms. This result is intuitive since large firms have limited growth opportunities providing managers with unfettered latitude to invest in value-destroying activities. Finally, we show that the 2007/08 financial crisis has marginal effects on the relationship between leverage and firm performance. Thus, we do not find evidence that leverage has a significant adverse impact on firm performance during the financial crisis compared with pre- and post-crisis periods.

We conduct several tests to ascertain the robustness of our results. First, we measure firm performance using alternative proxies such as Tobin's Q and ROA, and leverage as total leverage, short-term leverage and long-term leverage. Second, we partition the sample into firm size to explore the relative effects of leverage on firm performance. This analysis is necessary since firm size defines the level of growth opportunities and the extent of investment in value - 
destroying projects. Third, we focus on the effects of financial crisis on the leverage performance relationship. Here, we partition the sample into pre-crisis, crisis and post-crisis and re-estimate our base model to test the robustness of our results. In addition to OLS estimation, we use the fixed-effects model to deal with time-invariant covariates. Finally, we address the issue of endogeneity and reverse causality using 2-step GMM estimation. Our results remain robust to all the tests and alternative estimations used to analyse the data.

We contribute to the extant literature by studying the effects of leverage on firm performance, given firm size and the financial crisis. First, we complement the body of literature that examines the effects of leverage on firm performance (Berger and Di Patti, 2006; Margaritis and Psillaki, 2010). However, and more importantly, our study complements the evidence in this area by providing evidence for leverage-firm performance in an emerging economy, India. Second, we investigate the extent to which the effect of leverage on performance is conditional on the size of the firm. This evidence enhances our understanding of the effects of firm size on the leverage-performance relationship through the influence of growth opportunities. Finally, we depart from existing studies by examining the extent to which the 2007/08 financial crisis has impacted on the leverage-firm performance relationship. This analysis is particularly important given the impact of the financial crisis on investment and economic growth. Thus, our findings shed more insights into the effects of financial crisis on leverage-firm performance relationship. This finding has not yet been explored in the empirical literature, especially in an emerging economy context.

The rest of the paper is organised as follows: section 2 examines relevant literature and its theoretical underpinnings. In Section 3, we discuss the sample, empirical design and measurement of variables. We present the regression results and discussion in section 4 . Finally, section 5 provides a summary of the findings and concludes the discussion.

\section{Literature}

\subsection{The Indian context}

Rajan and Zingales (1995) highlight that institutional structures significantly account for variations in the leverage decisions of firms in major economies, of which India is no exception. Relatively, the relevance of such structures is dependent on whether the financial sector is predominantly characterised by a highly-developed banking system, corporate debt/bond 
market or a developed stock market. The distinction between these systems is reflected in the choice of debt against equity (private against public finance) (DeMiguel and Pindado, 2001). Thus, an overview of the unique features of India's economy puts our paper into perspective. In India, firm reliance on debt financing is arguably an exogenous determinant of firm performance. Over the last three decades, India has seen continuously rapid economic growth, although the financial sector is dominated by a large but inefficient banking sector (Allen et al., 2012).

Additionally, the ownership structure of firms in India is vested in a few hands and predominantly dominated by family ownership and ties. Indeed, the nature of corporate ownership in India reflects a pattern where about $75 \%$ of the largest Indian firms are family owned (Chakraborty, 2010). With this, the degree of reliance on the banking system is high to mitigate problems of ownership dilution. Existing evidence has shown that there are signific ant misallocations of financial resources in the Indian economy, ensuring that financing from nonbank and nonmarket sources mostly backed by nonlegal mechanisms constitutes the key form of external finance, followed by bank finance (Allen et al., 2012).

Other relevant notable features of the Indian economy include the institution of the 1991 financial liberalisation reforms which led to the institution of interest deregulation and easing of entry restrictions into the banking sector (Ataullah et al., 2004; Shanmugam and Das, 2004). This liberalisation facilitated the development of the banking system in terms of size, efficiency, competition and geographical spread (Jadiyappa et al., 2016). The reforms also facilitated an upsurge in financial innovations in the financial sector, ensuring that firms have better availability, access and freedom to choose debt instruments suitable to their funding needs (Jadiyappa et al., 2016). In general, the Indian economy is dominated by the banking sector and, especially, private banks dominate the national and foreign banks in terms of both productivity levels and growth (Sanyal and Shankar, 2011).

In addition to the above, other reforms have also been implemented aimed at ensuring that stock markets represent a viable and stable source of capital for firms in the country (Jadiyappa et al., 2016). As part of the liberalisation, the Capital Control Act (1947) which regulated the equity market was repealed to transfer sole regulatory authority to the Securities and Exchange Board of India (Bhaduri, 2002). Repealing the Capital Control Act offered firms more freedom to raise fresh capital, design and price new instruments, and decide on the size of capital issuance, hence encouraging many privately-owned firms to raise external finance through 
public offering (Ghosh, 2006, 2008). Between 1994 and 1995, the National Stock Exchange (NSE) and Bombay Stock Exchange (BSE) were established with mandates that permitted nationwide electronic trading and clearing and settlement facilities (Chakraborty, 2010).

The foregoing characteristics of the Indian economy undoubtedly shape the corporate financing decisions.

\subsection{Empirical review and hypotheses}

Our paper builds on a rich empirical literature to examine the leverage-performance relationship of Indian firms. Extant empirical evidence on the subject has recorded mixed conclusions. Consistent with Jensen (1986), Ofek (1993) shows that high leverage generally leads to higher firm performance. This is because high leverage is associated with binding covenants and monitoring, which ensures that management maintains operational discipline. Similarly, highly leveraged firms have a high degree of response to financial distress since management is able to rapidly implement operational measures (e.g. asset restructuring and employee lay-offs) or financial measures (e.g. dividend cuts, debt restructuring) when performance deteriorates. Hence, the use of leverage assists in the preservation of the firm's going concern value. Fama and French (2002) show that, to mitigate agency costs resulting from free cash flow, profitable firms commit large sums of their pre-interest earnings to debt payments. Hence, by controlling for investment opportunities, leverage must have a positive effect on firm performance. An extension to this leverage-performance relationship by Ruland and Zhou (2005) contends that the relationship is also dependent on the level of diversification and the degree of agency problems associated with a firm. Hence, a firm's performance is maximised when it accumulates leverage; this is particularly so for small-sized diversified firms associated with higher agency costs.

Conversely, the need to mitigate shareholder-debtholder conflicts (e.g. underinvestment, asset substitution) induces firms with more investments to opt for less leverage (Jensen and Meckling, 1976; Myers, 1977). This usually occurs when managers hold a significant proportion of a firm's equity, hence increasing the likelihood of managerial opportunism (Margaritis and Psillaki, 2010). Thus, by controlling for profitability, firms associated with lower earnings relative to their investments have less incentives for the discipline effect of leverage. The foregoing discussion shows the potential relationship between leverage and firm performance. However, on the whole, research on this issue from the context of India is scant 
to date. So far, the key papers that examine capital structure choices in India are Guha Khasnobis and Bhaduri (2002), Chakrabarty (2010), and Chadha and Sharma (2015). While Chakrabarty (2010) focused on examining the capital structure determinants of Indian firms, Guha-Khasnobis and Bhaduri, (2002) examined the key determinants of the speed of adjustment towards optimal capital structure. Key findings from both papers highlight the fact that important differences across firms in terms the firm-specific attributes (e.g. tangibility, size, payouts, tax, financial distress and profitability) account for capital structure optimality. Chadha and Sharma (2015) extended the above studies to examine the capital structure effect on firm performance. They concluded that leverage has no impact on financial performance of Indian firms. This finding is not surprising given that their study has some limitations: (i) they relied on data for only manufacturing firms; (ii) although the overall Indian manufacturing industry comprises about nine sub-industries, their sample size comprised just 422 firms. Thus, in response, we provide new evidence on the link between leverage and firm performance by using a more sophisticated sample comprising 2403 Indian firms from every sector (excluding financials and industrials). We also specifically highlighted the role of firm size as well as the impact of the 2007/08 global financial crisis on this leverage performance relationship.

\subsubsection{Leverage and firm performance}

In this paper, we examine the leverage-performance nexus by focusing on firms in India. First, the Indian financial sector is significantly characterised by misallocation of financial resources, ensuring that financing from nonbank and nonmarket sources mainly backed by nonlegal mechanisms constitutes the key form of external finance before bank finance (Allen et al., 2012). Moreover, the nature of corporate ownership in India reflects that the largest Indian firms are predominantly family owned (Chakraborty, 2010). Hence, the bank incentive for monitoring clients in family-owned institutions may not be very significant; also, banking relationships under such conditions may be important. Firm owners or managers may be aware of the debt-monitoring inefficiency, implying that an increase in leverage means more cash to undertake inefficient or discretionary investments, which negatively affects firm performance.

Furthermore, debt overhang problems may lead to underinvestment and consequently drive poor performance (Myers, 1977). Thus, even when highly leveraged firms identify new and positive net present value (NPV) investment projects, they may lack the ability to issue new debt. Where they do issue new debt, given that earnings generated from new investments are 
directed towards payments on existing debts, new debtors may be unable to obtain adequate payments from the earnings of any new projects (Tsuruta, 2015). Consequently, banks and other lenders may be discouraged from financing new projects even though the NPVs are positive. This is particularly so given the Indian financial sector is dominated by an inefficient banking sector (Allen et al., 2012). The inability to raise further funding due to high leverage will ensure that firms are deprived of probable profits from highly profitable future investment opportunities that they lack the ability to undertake.

Moreover, high leverage is associated with greater average bankruptcy risk (Altman 1984). For creditors, the presence of asymmetric information and agency problems inhibits effective monitoring and discipline for managers (Harris and Raviv, 1990; Danso et al., 2019a). Consequently, lenders are discouraged from lending to highly geared firms even when their investments have positive NPVs. In the India context, the asymmetric information is more severe given that the ownership structure of firms is vested in a few hands and predominantly dominated by family ownership and ties (Chakraborty, 2010). Furthermore, while lenders (e.g. large banks) may lessen the asymmetric information bias for Indian firms by relying on hard information (for instance from firms' financial statements) (Cole et al. 2004), they may restrict financing particularly for highly leveraged smaller firms even if they produce high-quality financial statements or have highly profitable investment opportunities (Van Caneghem and Van Campenhout, 2012). This is particularly so because, in India, private banks dominate the national and foreign banks in terms of both productivity levels and growth (Sanyal and Shankar, 2011). Therefore, private banks are more likely to champion their private profitability objectives rather than the systemic goal of ensuring free fund flow to smaller and highly leverage firms to enhance their survivability. Grounded on the above, we contend that highly leveraged firms operating in an emerging market like India will perform poorly relative to their unleveraged counterparts. We therefore formulate the following hypothesis:

Hypothesis 1: Corporate leverage is negatively related to performance of Indian firms.

\subsubsection{Leverage and firm performance: the role of size}

The corporate finance literature primarily focuses on the cost of high leverage in the examination of the size effect. However, particularly for emerging markets like India, the gains of high leverage are yet to be established. Given that ownership in India is such that the largest Indian firms are family owned, this ownership system may not mandate effective reporting to 
external shareholders, and so effective performance monitoring systems may be lacking (Chakraborty, 2010). If firms utilise more debt (i.e. bank loans or trade credit), banks and other trade partners can monitor their activities to mitigate inefficient management practices. Smaller firms are more likely to reap the advantages of this increased monitoring. For smaller firms, agency problems between shareholders and managers, as well as the free cashflow problems, are mitigated given that ownership and control generally are not separated (Berger and Udell, 1998).

Moreover, the threat of defaults on future debt payments enhances firm efficiency (Jensen, 1986). Because debt requires managers to transfer a portion of the benefits derived from investments to debtholders, managers of highly geared firms may be tempted to reject valuable investment opportunities, consequently resulting in suboptimal investments and/or reduction in the firm's performance and value (Myers, 1977). Furthermore, the fear of default on future debt payments discourages firms from accumulating further debt, and leads them to prefer to finance profitable investment opportunities with own funds. For smaller firms, owners may lose their personal assets when their firm defaults since their assets are usually collateralised for the debt (Tsuruta, 2015). Therefore, the incentive for efficient management is strong in highly leveraged small firms. Lastly, where highly geared but smaller firms have better access to credit, they become more competitive (Campello 2006). However, this worsens asymmetric information between small firms and lenders, and thus results in credit rationing for smaller firms (Danso et al., 2019a). Given that private banks dominate the national banks, the private banks will adopt innovative means of achieving their private profitability objectives. It is therefore not surprising that firm financing in India is mostly backed by nonlegal mechanis ms (Allen et al., 2012). In this case, highly leveraged but smaller firms and their lenders might mitigate the information problems through the use of innovative lending technologies towards improving the performance of these small firms (Berger and Udell 2006). Grounded on the above, we hypothesise that:

Hypothesis 2: Corporate leverage has a more negative impact on firm performance for larger firms than smaller firms.

\subsubsection{Leverage and firm performance: does crisis matter?}

The financial crisis adversely affected global liquidity and increased the cost of borrowing. The Indian financial sector is not deeply integrated with the global financial system and thus, Indian 
banks and financial institutions remained largely unaffected (Prasad and Reddy, 2009). Nevertheless, as the financial crisis distorted global economies, India could not escape the adverse effects. The global crisis impacted the Indian economy through three distinct channels: financial markets, trade flows and exchange rates (Kumar and Vashisht, 2012). This consequently constrained firms' growth opportunities, their ability to borrow and invest, and performance (Campello et al., 2010; Danso et al., 2019b). Although the strict regulations and conservative policies adopted by the Reserve Bank of India ensured that the financial sector is relatively safeguarded against the struggles of their western counterparts (Prasad and Reddy, 2009), examining the effect of the financial crisis provides a great opportunity to capture the adverse effects of a less optimal capital structure. As noted by Ho et al. (2016), highly geared firms experienced greater likelihood of financial distress and reduced profitability during the crisis. Consequently, the debt level became an important signal for firm survival (Campello et al., 2010). We therefore expect that highly geared firms are more likely to suffer more unfavourable consequences than their ungeared counterparts after the busting of a credit boom. Moreover, it is also evident that the crisis impact varies based on the choice of debt alternative, short vs long. Prior evidence suggests an increased priority for short-term debt during the crisis (see e.g. Custódio et al., 2013). A key reason for this trend is that firms faced a higher degree of information asymmetry during the crisis. As such, lenders become more hesitant to provide long-term funding during crises, which makes short-term debt more attractive towards alleviating performance challenges (Gürkaynak and Wright, 2012; Dick et al., 2013). Grounded on the above, we contend that Indian firms that have or require significant long-term funding will have a particularly poor performance relative to their short-term counterparts during the crisis period. Taken together, we formulate the following hypotheses:

Hypothesis 3A: The leverage-performance nexus will be more pronounced during crisis periods.

Hypothesis 3B: Long-term leverage is more detrimental to firm performance during crisis periods.

\section{Methodology}

\subsection{Data and variables}


To gauge the relationship between leverage and firm performance, annual financial data for 2403 Indian firms were obtained from the DataStream database for the period 1995-2013. Availability of data guided the selection of the firms. In all, a total number of 19,544 firm-year observations were used in our regression analyses.

All the variables used in this study were chosen in line with the earlier discussed empirical and theoretical literature. This should enable us to compare our results with prior research. We use Tobin's $\mathrm{Q}(T Q)$ as a proxy for firm performance. Our independent variables are Overall Leverage (LEV), Long-term Leverage (LTLev) and Short-term Leverage (STlev). Additionally, we control for a number of variables in our econometric models. These control variables are firm size $(S Z)$, firm growth $(G R)$, asset tangibility $(T A N)$, non-debt tax shield (NDTS) and firm investment $(I N V)$. In addition, we follow existing literature (e.g. Fosu et al., 2016; Dudley, 2012; Maury and Pajuste, 2005) and winsorise all variables at a 5\% level on either tail to mitigate the effect of outliers. A summary of the variables used is presented in Table 1 below.

\section{Insert Table 1 about here}

\subsection{Descriptive statistics and correlations}

In Table 2, we present the summary statistics of the variables used in this study over the whole sample period. The information is confined to 2403 Indian firms during the period 1995-2014, generating a total of 19,544 firm-year observations. A few findings are worth pointing out. The average value of firm performance $(T Q)$ is 1.70 and has a standard deviation of 0.87 . This variable has a minimum value of 0.89 and a maximum value of 4.17 , signifying a fair degree of heterogeneity. Also, the average value of overall leverage $(L E V)$ is 0.31 . This low figure may reflect the fact that Indian firms are mainly equity financed. The average value of longterm leverage is 0.19 . Short-term leverage (STlev) has an average value of 0.13 . This shows that the greater portion of the capital structure of most of the firms studied is long-term debt. Firm size (SZ) has a mean value of 14.77 and a standard deviation of 1.60 . This variable has a minimum and maximum value of 11.89 and 17.81 respectively, signifying a fair degree of heterogeneity. We also observe that firm growth $(G R)$ has a mean value of 0.20 and a standard deviation of 0.333 . This variable has a minimum value of -0.36 and a maximum value of 1.04 . 
This suggests that some of the firms investigated experienced a negative growth.

Insert Table 2 about here

Turning our attention to Table 3, we investigate whether the independent variables employed are likely to suffer from collinearity problems. We first note that the correlation between our two independent variables (Lev and LTlev) is very high (0.82). This suggests that both variables are capturing a similar aspect. However, this poses no concerns about multicollinearity as these variables do not enter the regression at the same time. We also observe that the correlation (but not necessarily the causal relationship) between our dependent $(T Q)$ and independent variables (LEV, LTLev and STLev) is negative. With regard to the control variables, the correlation among them (as presented in Table 3) reveals there is no multicollinearity issue. Generally, our descriptive statistics, as well as the correlation matrix, suggest that our sample firms do not suffer from any serious issues such as lack of variation, heterogeneity and large outliers.

\section{Insert Table 3 about here}

\subsection{Estimation method}

In this section, we formulate our empirical models to test our relationships. We formulate the following baseline regression model:

$$
T Q_{i, t}=\alpha+\lambda_{t}+\beta X_{i, t-1}+\varepsilon_{i, t-1}
$$

Where $T Q$ (Tobin's Q) is our measure of firm performance (defined), $X$ is the matrix of the independent and control variables previously referenced and defined in Table 1 , and $\varepsilon$ is a composite error term including time-invariant firm-fixed effects and an independently and identically distributed component with mean zero: 
$\varepsilon_{i, t-1}=\mu_{i}+v_{t-1}$

To test the relationship between our dependent $(T Q)$ and independent variables (Lev, LTlev and STlev), each of the independent variables enters the regression equation alternatively.

To control for the effect of financial crisis, we estimate Eq. (1) and Eq. (2) for the full sample and separate sub-samples of pre-crisis, crisis and post-crisis periods.

We can estimate our models, Eq. (1) and Eq. (2), using OLS. However, this estimation approach fails to control for unobserved firm-level heterogeneity, leading to biased and inconsistent estimates (Wooldridge, 2009, p. 246). Hence, a practical approach is to adopt a panel fixed-effects or random-effects estimation method. We confirm, using the Hausman test, that the fixed-effects models (FEs) are most appropriate to account for the firm-level heterogeneity. Therefore, we base our analysis on the panel fixed-effects models and use the pooled OLS for robustness checks. To control for possible heteroscedasticity and autocorrelation within firms, standard errors of our regression coefficients are adjusted using Huber-White approach and clustering at the firm level. Finally, we follow the extant literature (e.g. Danso and Adomako, 2014; Mc Namara et al, 2017) and lag the explanatory variables by one period. This is to isolate the analysis from the potential reverse causality between dependent and independent variables.

\section{Results and Discussion}

This section presents the paper's estimation results. We first present the results for our baseline models, where firm performance is explained by our three independent variables (Lev, LTLev and STLev). This result is presented in Table 4 below. We then follow this up by checking the robustness of our results (Tables 5 and 6). Next, we examine the extent to which firm size matters in the leverage-performance relationship (Table 7). Finally, we look at how the 2007/08 global financial crisis impacted on the leverage-firm performance relationship (Table 8).

\subsection{Leverage and firm performance}


Our baseline results are presented in Table 4. Two main estimation methods are employed: OLS and fixed-effects models. Models 1-2, 5-6 and 9-10 are based on OLS whilst the remaining models are based on fixed effects. Across all models, all our independent variables are negative and significantly related to firm performance at the $1 \%$ level. The Hausman specification test performed provided support for the fixed-effects estimation and therefore we discuss our results using the fully specified fixed-effects model estimations. The OLS models are therefore used as a robustness check. We start the discussion of our results with model 4, where overall leverage (LEV) is negatively and significantly related to firm performance. This suggests that a one unit increase in financial leverage is associated with a 0.75 percentage point decrease in firm performance. Hence, in economic terms, a one standard deviation increase in the financial leverage will decrease firm performance by up to $21.4 \%$. This finding is generally consistent with other empirical works (e.g. Le and Bich 2017). The coefficient on long-term leverage (LTLev) as indicated by model 8 (i.e. the fully specified FE model) is negative and significant at the $1 \%$ level. Based on this result, a one standard deviation increase in LTLev is associated with a $13.9 \%$ decrease in firm performance. Turning our attention to short-term leverage (STLev), we find that STLev (as in model 12) is negatively associated with firm performance. This effect is statistically significant at the $1 \%$ level. The coefficient of this variable is -0.747 with a standard deviation of 0.11 . Hence, in economic terms, a one standard deviation increase in STLev will decrease firm performance by $8.2 \%$. This suggests that an increase in STLev is associated with a decrease in firm performance. The negative relationship between leverage and firm performance may be attributable to a few unique factors pertaining to emerging or transition markets like India. The Indian financial sector is significantly characterised by misallocation of financial resources, ensuring that financing from nonbank and nonmarket sources mainly backed by nonlegal mechanisms constitutes the key form of external finance before bank finance (Allen et al., 2012). Moreover, the nature of corporate ownership in India reflects that the largest Indian firms are predominantly family owned (Chakraborty, 2010). Hence, the bank incentive for monitoring clients in family-owned institutions may not be very significant; also, banking relationships under such conditions may be important. Firm owners or managers may be aware of the debt-monitoring inefficiency, implying that an increase in leverage means more cash to undertake inefficient or discretionary investments, which negatively affects firm performance. Hence, as noted by Nielsson (2013) and Park et al. (2013), our findings support the view that a low level of leverage indicates a high level of firm quality, which may be manifested through high profitability. Our findings 
are broadly consistent with other empirical evidence (see Vithessonthi and Tongurai, 2015a, b; Le and Bich, 2017).

Turning our attention to the control variables, we find that firm growth (GR) and level of investment (INV) have positive and significant effects across all models, supporting the findings of Margaritis and Psillaki (2010) and Le and Bich (2017). This shows that growth and investment enhance firm performance and value. Although NDTS is positive across all models, the effect of this variable is only significant with our OLS models. We find that NDTS has no significant effects on performance in any of our FE models. Firm size (SZ) has a negative and significant effect across all our FE models. This means that firm size reduces the extent of firm performance, possibly because large firms tend to be inefficient (see Williamson, 1967; Margaritis and Psillaki, 2010). We also observe that TAN has non-monotonic effects across our models.

\section{Insert Table 4 about here}

\subsection{Robustness check}

\subsubsection{Leverage and firm performance-GMM estimation}

So far, we have documented that LEV, LTLev and STLev have a negative and significant impact on firm performance. The natural progression at this stage is to probe the robustness of our results. Thus, in this section, we address the potential endogeneity problems that are likely to plague our findings. Such problems may arise from possible reverse causality between financial leverage and firm performance. Although lagged values of our independent variables are used in the above models to mitigate such simultaneity bias, to fully address the simultaneity issues and omitted variable bias in respect of leverage, we follow extant literature (e.g. Fosu, 2013; Ozkan, 2001) and re-estimate our models using the 2-step Generalised Method of Moments (GMM) technique. The result is presented in Table 5.

Insert Table 5 about here 
Comparing our GMM results, reported in Table 5, with the results in Table 4, we observe that they are qualitatively similar. The signs of our estimated coefficients remain the same. Particularly, the coefficient of LEV as reported in the first column of Table 5 remains negative and significant at the $1 \%$ level. This confirms our earlier findings that financial leverage leads to lower firm performance. The coefficients of LTLev and STLev are negative and signific ant. Overall, the findings reported in Table 5 suggest that our earlier results in Table 4 are less likely to be driven by simultaneity between financial leverage and firm performance.

\subsubsection{Using an alternative measure of firm performance - ROA}

The results obtained so far are based on Tobin's Q (TQ) as our measure of firm performance. In this section, we assess the sensitivity of our results to an alternative measure of firm performance (i.e. return on assets - ROA - defined as total operating profit plus depreciation and amortisation divided by total assets). The results of this are presented in Table 6 . We observe from the results that the signs on the coefficients of our three independent variables (Lev, LTLev and STLev) do not change. Overall, the magnitude of our estimated coefficients of the independent variables remains negative and significant across all models. This is a confirmation of the findings we obtained in tables 4 and 5 when TQ was used as a dependent variable.

\section{Insert Table 6 about here}

\subsection{Leverage, size and firm performance}

In this sub-section, we extend our baseline model presented in section 3.4 by examining the extent to which firm size matters in the leverage-performance relationship. To do this, we use $\log$ of total assets as a proxy for firm size and split our sample firms into quantiles where the firms in the top one-third quantile of the log of total assets are marked as larger firms, whilst those in the bottom one-third quantile are marked as smaller firms. The results of this are presented in Table 7. 


\section{Insert Table 7 about here}

First, the results are consistent with and complementary to our main findings that leverage and performance are negatively related. However, we observe from Table 7 that the magnitude of the effect increases with firm size. For instance, in economic terms for larger firms, a standard deviation change in LEV reduces firm performance by as much as $62.30 \%$, whilst, in smaller firms, a standard deviation increase in LEV is associated with up to a $22.37 \%$ reduction in firm performance. Also, in larger firms, a standard deviation increase in LTLev could lead to up to a $51.74 \%$ reduction in firm performance. In smaller firms, however, a standard deviation increase in LTlev could lead to up to a $15.63 \%$ decrease in performance. In addition, a one standard deviation increase in STLev could reduce firm performance by up to $38.76 \%$ for larger firms and $15.08 \%$ for smaller firms. Thus, leverage has a more negative impact on firm performance for larger firms than smaller firms.

This finding confirms hypothesis 2 , which suggests that the high family ownership of the largest Indian firms may not mandate effective reporting to external shareholders, and so effective performance monitoring systems may be lacking (Chakraborty, 2010). For smaller firms, agency problems between shareholders and managers, as well as the free cashflow problems, are mitigated given that ownership and control generally are not separated. Furthermore, small firm owners may lose their personal assets when their firm defaults since their assets are usually collateralised for the debt (Tsuruta, 2015). Therefore, the incentive for efficient management is strong in highly leveraged small firms. Even where asymmetric information worsens between small firms and lenders, private lenders will adopt innovative means of achieving their private profitability objectives. In this case, highly leveraged but smaller firms and their lenders might mitigate the information problems through the use of innovative lending technologies towards improving the performance of these small firms (Berger and Udell 2006). Therefore, although the high constraints of smaller firms may limit effective actualisation of investment opportunities, as suggested by Paulson and Townsend (2004), smaller firms are more likely to mitigate the adverse effects of agency costs on firm performance than larger firms. 


\subsection{Leverage, crisis and firm performance}

So far, we have shown the role of financial leverage in influencing firm performance and the extent to which firm size matters in this relationship. In this sub-section, we build on our baseline model regression in Table 4 and investigate whether the 2007/08 crisis impacted on the relationship between financial leverage and firm performance of Indian firms. To do this, we split our data into three sample periods (i.e. pre-crisis, crisis and post crisis) and re-estimate the regression models. We present the results in Table 8 .

\section{Insert Table 8 about here}

We find that, generally, the contribution of LEV (i.e. negative) has not been significantly affected by the financial crisis as the sub-samples' relationship and statistical significance remain similar across the three sample periods. However, the magnitude of this effect (in absolute terms) is larger during the crisis than in the pre- and post-crisis periods; therefore, confirming hypothesis $3 \mathrm{~A}$ that highly geared firms experienced greater likelihood of financial distress and reduced profitability during the crisis period.

Further, we observe that the coefficient for both LTLev and STLev remains negative and statistically significant across all sample periods. However, the magnitude of the effect of LTLev (STLev) on TQ increased (decreased) during the crisis period before decreasing in the post-crisis period. With increasing information asymmetry during the crisis, lenders became more hesitant to provide long-term funding, which made short-term debt more attractive towards alleviating performance challenges (Dick et al., 2013). Therefore, as indicated in hypothesis 3B, LTlev relative to STLev was more detrimental to firm performance in the crisis period. Following robust regulations over the crisis period, the post-crisis period envisaged an improvement in the leverage-performance nexus where a fundamental increase in financial leverage is associated with better but still inefficient debt monitoring and discipline (Danso et al., 2019b). Consequently, firm owners or managers continued to take advantage of this inefficiency, implying that an increase in leverage continues to affect firm performance 
negatively. Overall, we provide evidence suggesting that financial leverage and firm performance relationship show varied levels of sensitivity to the financial crisis.

\section{Conclusion}

Following the seminal papers of Modigliani and Miller (1958, 1963), the findings of prior studies offer a mixed conclusion on the relationship between financial leverage and firm performance. Thus, in this paper, we seek to offer a fresh perspective to the growing literature on the leverage-performance nexus, with a specific focus on Indian firms. In particular, we provide first-hand evidence using a sample of 2403 firms with 19,544 firm-year observations. Notably, evidence presented here indicates that financial leverage leads to a decrease in firm performance. Also, we observe that the impact of financial leverage on firm performance is lower for smaller firms than larger ones. By way of extension, we also find that the recent global financial crisis, to a certain degree, affected the relationship between financial leverage and firm performance. These findings are novel and remain robust to an alternative econometric method (GMM).

Indeed, the study offers a number of theoretical and practical implications. From a theoretical perspective, we extend the capital structure literature by demonstrating the impact of leverage on firm performance and the extent to which firm size and financial crisis matter in this relationship. Our study suggests that greater financial leverage leads to a lower firm performance in developing countries where firms are confronted with difficulties with raising equity finance. Beyond the theoretical implication, this study offers a practical implication. By providing new insights on the leverage-performance relationship, we show how leverage can be detrimental to firm performance. Thus, it is important for firms to reduce the amount of leverage adopted in their capital structure - particularly larger firms and also in times of financial crisis when access to finance is deeply constrained.

There are a few limitations worth noting. First, our study is based on India - one of the emerging economies across the globe. Although India shares many characteristics with other emerging economies, this is not enough to provide a basis for the generalisation of our findings. It is important to point out that there are certain institutional differences across different economies. There is a possibility that the leverage-performance relationship might differ from other developing contexts. Thus, future studies should offer further insight by extending our findings to other emerging economies. Future studies may also consider whether managerial 
characteristics matter for leverage choices in emerging markets. Additionally, a broad-based study targeting both developing and developed countries is warranted. Also, comparison of studies along industrial lines can be carried out to understand the leverage-performance relationship on an industrial basis.

\section{References}

Allen, F., Chakrabarti, R., De, S., and Qian, M. (2012), "Financing firms in India", Journal of Financial Intermediation, Vol. 21 No.3, pp. 409-445.

Anderson, R. C., Mansi, S. A., and Reeb, D. M. (2004), "Board characteristics, accounting report integrity, and the cost of debt", Journal of Accounting and Economics, Vol. 37 No. 3, pp. 315-342.

Antoniou, A., Guney, Y., and Paudyal, K. (2008), "The determinants of capital structure: Capital market-oriented versus bank-oriented institutions", Journal of Financial and Quantitative Analysis, Vol. 43 No. 1, pp. 59-92.

Ataullah, A., Cockerill, T., and Le, H. (2004), "Financial liberalization and bank efficiency: A comparative analysis of India and Pakistan”, Applied Economics, Vol. 36 No. 17, pp. 1915-1924.

Berger, A. N., and Di Patti, E. B. (2006), "Capital structure and firm performance: A new approach to testing agency theory and an application to the banking industry", Journal of Banking and Finance, Vol. 30 No. 4, pp. 1065-1102.

Berger, A. N. and Udell, G. F. (1998), "The economics of small business finance: The roles of private equity and debt markets in the financial growth cycle", Journal of banking and finance, Vol. 22 No. 6-8, pp. 613-673.

Berger, P. G., Ofek, E., and Yermack, D. L. (1997), "Managerial entrenchment and capital structure decisions", The Journal of Finance, Vol. 52 No. 4, pp. 1411-1438.

Bergman, U. M., and Hutchison, M. (2015), 'Economic stabilization in the post-crisis world: Are fiscal rules the answer?", Journal of International Money and Finance, Vol. 52 No. (C), pp. 82-101.

Bhaduri, S. N. (2002), "Determinants of capital structure choice: A study of the Indian corporate sector", Applied Financial Economics, Vol. 12 No. 9, pp. 655-665.

Bremus, F., and Fratzscher, M. (2015), "Drivers of structural change in cross-border banking since the global financial crisis", Journal of International Money and Finance, Vol. 52 No. (C), pp. 32-59.

Campello, M. (2006), 'Debt financing: Does it boost or hurt firm performance in product Markets?", Journal of Financial Economics, Vol. 82 No. 1, pp. 135-172.

Campello, M., Graham, J. R., and Harvey, C. R. (2010), 'The real effects of financial 
constraints: Evidence from a financial crisis", Journal offinancial Economics, Vol. 97 No. 3 , pp. 470-487.

Cerutti, E. (2015), "Drivers of cross-border banking exposures during the crisis", Journal of Banking and Finance, Vol. 55 No. (), pp. 340-357.

Cerutti, E., Hale, G., and Minoiu, C. (2015), "Financial crises and the composition of crossborder lending", Journal of International Money and Finance, Vol. 52 No. @), pp. 60-81.

Chadha, S., and Sharma, A. K. (2015), "Determinants of capital structure: An empirical evaluation from India”, Journal of Advances in Management Research, Vol. 12 No. 1 pp. 3-14.

Chakraborty, I. (2010), "Capital structure in an emerging stock market: The case of India", Research in International Business and Finance, Vol. 24 No. 3, pp. 295-314.

Chava, S., and Roberts, M. R. (2008), "How does financing impact investment? the role of debt covenants", The Journal of Finance, Vol. 63 No. 5, pp. 2085-2121.

Chen, J. J. (2004), 'Determinants of capital structure of Chinese-listed companies”, Journal of Business Research, Vol. 57 No. 12, pp. 1341-1351.

Cole, R. A., Goldberg, L. G., and White, L. J. (2004), "Cookie cutter vs. character: The micro structure of small business lending by large and small banks", Journal of Financial and Quantitative Analysis, Vol. 39 No. 2, pp. 227-251.

Connelly, J. T., Limpaphayom, P., and Nagarajan, N. J. (2012), "Form versus substance: The effect of ownership structure and corporate governance on firm value in Thailand", Journal of Banking and Finance, Vol. 36 No. 6, pp. 1722-1743.

Custódio, C., Ferreira, M. A., and Laureano, L. (2013), "Why are US firms using more shortterm Debt?”, Journal of Financial Economics, Vol. 108 No. 1, pp. 182-212.

Danso, A., and Adomako, S. (2014), "The financing behaviour of firms and financial crisis", Managerial Finance, Vol. 40 No. 12, pp. 1159-1174.

Danso, A., Lartey, T., Fosu, S., Owusu-Agyei, S., and Uddin, M. (2019a), 'Leverage and firm investment: the role of information asymmetry and growth", International Journal of Accounting and Information Management, Vol. 27 No. 1, pp. 56-73.

Danso, A., Lartey, T., Amankwah-Amoah, J.Adomako, S., Lu, Q., Uddin, M. (2019b), "Market sentiment and firm investment decision-making", International Review of Financial Analysis, Vol. 66 No. 101369.

De Miguel, A., and Pindado, J. (2001), "Determinants of capital structure: New evidence from Spanish panel data", Journal of Corporate Finance, Vol. 7 No. 1, pp. 77-99.

Dick, C. D., Schmeling, M., and Schrimpf, A. (2013), 'Macro-expectations, aggregate uncertainty, and expected term premia", European Economic Review, Vol. 58 No.(C), pp. 58-80.

Dudley, E. (2012), "Capital structure and large investment projects", Journal of Corporate Finance, Vol. 18 No. 5, pp. 1168-1192. 
Dungey, M., and Gajurel, D. (2015), "Contagion and banking crisis-International evidence for 2007-2009”, Journal of Banking and Finance, Vol. 60, pp. 271-283.

Fama, E. F., and French, K. R. (2002), "Testing trade-off and pecking order predictions about dividends and debt", The Review of Financial Studies, Vol. 15 No. 1, pp. 1-33.

Fosu, S. (2013), "Capital structure, product market competition and firm performance: Evidence from South Africa", Quarterly Review of Economics and Finance, Vol. 53 No. $2,140-151$.

Fosu, S., Danso, A., Ahmad, W., and Coffie, W. (2016), "Information asymmetry, leverage and firm value: Do crisis and growth matter?", International Review of Financial Analysis, Vol. 46 , pp. 140-150.

Ghosh, S. (2006), "Did financial liberalization ease financing constraints? evidence from Indian firm-level data", Emerging Markets Review, Vol. 7 No. 2, pp. 176-190.

Ghosh, S. (2008), "Leverage, foreign borrowing and corporate performance: Firm-level evidence for India", Applied Economics Letters, Vol. 15 No. 8, pp. 607-616.

Guha-Khasnobis, B., and Bhaduri, S. N. (2002), "Determinants of capital structure in India (1990-1998): a dynamic panel data approach", Journal of Economic Integration, Vol. 17 No. 4, pp. 761-776.

Gürkaynak, R.S., Wright, J. H. (2012), "Macroeconomics and the term structure", Journal of Economic Literature, Vol. 50 No. 2, pp. 331-67.

Harris, M., Raviv, A. (1990), "Capital structure and the informational role of debt", The Journal of Finance, Vol. 45 No. 2, pp. 321-349.

Ho, P. H., Huang, C. W., Lin, C. Y., and Yen, J. F. (2016), "CEO overconfidence and financial crisis: Evidence from bank lending and leverage", Journal of Financial Economics, Vol. 120 No. 1, pp. 194-209.

Jadiyappa, N., Vanga, N. R., and Krishnankutty, R. (2016), "Financial liberalisation and capital structuring decisions of corporate firms: Evidence from India", Economics Letters, Vol. 149, pp. 33-37.

Jensen, M. C. (1986), "Agency costs of free cash flow, corporate finance, and takeovers", The American Economic Review, Vol. 76 No. 2, pp. 323-329.

Jensen, M. C., and Meckling, W. H. (1976), 'Theory of the firm: Managerial behavior, agency costs and ownership structure", Journal of Financial Economics, Vol. 3 No. 4, pp. 305360 .

Jiraporn, P., and Liu, Y. (2008), "Capital structure, staggered boards, and firm value", Financial Analysts Journal, Vol. 64 No. 1, pp. 49-60.

Kahle, K. M., and Stulz, R. M. (2013), "Access to capital, investment, and the financial crisis", Journal of Financial Economics, Vol. 110 No. 2, pp. 280-299.

Kumar, R., and Vashisht, P. (2009), "The global economic crisis: Impact on India and policy Responses", ADBI Working Paper, No. 164, pp. 1 - 29. 
Kumbhakar, S., and Sarkar, S. (2003), "Deregulation, ownership, and productivity growth in the banking industry: Evidence from India", Journal of Money, Credit, and Banking, Vol. 35 No. 3, pp. 403-424.C

Le, T. P. V., and Bich, N. P. T. (2017), "Capital structure and firm performance: Empirical evidence from a developing country", Research in International Business and Finance, Vol. 42, pp. $710-726$

Margaritis, D., and Psillaki, M. (2010), "Capital structure, equity ownership and firm performance", Journal of Banking and Finance, Vol. 34 No. 3, pp. 621-632.

Maury, B., and Pajuste, A. (2005), "Multiple large shareholders and firm value", Journal of Banking and Finance, Vol. 29 No. 7, pp. 1813-1834.

Mc Namara, A., Murro, P., and O'Donohoe, S. (2017), "Countries lending infrastructure and capital structure determination: The case of European SMEs", Journal of Corporate Finance, Vol. 43 No. (C), pp. 122-138.

Modigliani, F., and Miller, M. H. (1958), "The cost of capital, corporation finance and the theory of investment", The American Economic Review, Vol. 48 No. 3, pp. 261-297.

Modigliani, F., and Miller, M. H. (1963), "Corporate income taxes and the cost of capital: A correction”, The American Economic Review, Vol. 53 No. 3 pp. 433-443.

Myers, S. C. (1977), 'Determinants of corporate borrowing”, Journal of Financial Economics, Vol. 5 No. 2, pp. 147-175.

Nielsson, U. (2013), "Do less regulated markets attract lower quality firms? evidence from the London AIM market”, Journal of Financial Intermediation, Vol. 22 No. 3, pp. 335-352.

Ofek, E. (1993), "Capital structure and firm response to poor performance: An empirical analysis", Journal of Financial Economics, Vol. 34 No. 1, pp. 3-30.c

Ozkan, A. (2001), "Determinants of capital structure and adjustment to long run target: Evidence from UK company panel data", Journal of Business Finance and Accounting, Vol. 28 No. 1-2, pp. 175-198.

Park, S. H., Suh, J., and Yeung, B. (2013), "Do multinational and domestic corporations differ in their leverage policies?", Journal of Corporate Finance, Vol. 20 No. (C), pp. 115-139.

Paulson, A. L., and Townsend, R. (2004), "Entrepreneurship and financial constraints in Thailand", Journal of Corporate Finance, Vol. 10 No. 2, pp. 229-262.

Prasad, A., and Reddy, C. P. (2009), "Global financial crisis and its impact on India", Journal of Social Sciences, Vol. 21 No. 1, pp. 1-5.

Qian, M., and Yeung, B. Y. (2015), "Bank financing and corporate governance" Journal of Corporate Finance, Vol. 32, pp. 258-270.

Rajan, R. G., and Zingales, L. (1995), "What do we know about capital structure? some evidence from international data", Journal of Finance, Vol. 50 No. 5, pp. 1421-1460.

Ruland, W., and Zhou, P. (2005), “Debt, diversification, and valuation”, Review of Quantitative Finance and Accounting, Vol. 25 No. 3, pp. 277-291. 
Santos, J. A. (2010), "Bank corporate loan pricing following the subprime crisis", The Review of Financial Studies, Vol. 24 No. 6, pp. 1916-1943.

Sanyal, P., and Shankar, R. (2011), "Ownership, competition, and bank productivity: An analysis of Indian banking in the post-reform period", International Review of Economics and Finance, Vol. 20 No. 2, pp. 225-247.

Shanmugam, K. R., and Das, A. (2004), "Efficiency of Indian commercial banks during the reform period”, Applied Financial Economics, Vol. 14 No. 9, pp. 681-686.

Singla, C., and George, R. (2013), "Internationalization and performance: A contextual analysis of Indian firms", Journal of Business Research, Vol. 66 No. 12, pp. 2500-2506.

Stulz, R. (1990), "Managerial discretion and optimal financing policies", Journal of Financial Economics Vol. 26 No. 1, pp. 3-27.

Taub, A. J. (1975), 'Determinants of the firm's capital structure”, The Review of Economics and Statistics, Vol. 57 No. 4, pp. 410-416.

Tsuruta, D. (2015), 'Leverage and firm performance of small businesses: evidence from Japan”, Small business economics, Vol. 44 No. 2, pp. 385-410.

Van Caneghem, T., and Van Campenhout G. (2012), "Quantity and quality of information and SME financial structure", Small Business Economics, Vol. 39 No. 2, pp. 341-358.

Vithessonthi, C., and Tongurai, J. (2015a), "The effect of firm size on the leverageperformance relationship during the financial crisis of 2007-2009", Journal of Multinational Financial Management, Vol. 29, pp. 1-29.

Vithessonthi, C., and Tongurai, J. (2015b), "The effect of leverage on performance: Domestically-oriented versus internationally-oriented firms", Research in International Business and Finance, Vol. 34, pp. 265-280.

Vo, X. V. (2017), "Determinants of capital structure in emerging markets: Evidence from Vietnam", Research in International Business and Finance, Vol. 40, pp. 105-113.

Wald, J. K. (1999), "How firm characteristics affect capital structure: An international comparison", Journal of Financial Research, Vol. 22, pp. 161-187.

Weill, L. (2008), "Leverage and corporate performance: Does institutional environment matter?", Small Business Economics, Vol. 30, pp. 251-265.

Williamson, O. E. (1967), "Hierarchical control and optimum firm size", Journal of Political Economy, Vol. 75 No. 2, pp. 123-138.

Wooldridge, J. M. (2009), "Introductory econometrics: A modern approach, South-Western Cengage learning”, pp. $1-862,5^{\text {th }}$ Edition, Nelson Education, Ltd, Canada, ISBN-13: 978. 
Table 1: Description of Variables

\begin{tabular}{|c|c|c|}
\hline Variable & Description & Literature \\
\hline \multicolumn{3}{|c|}{ Dependent Variable } \\
\hline Tobin's Q & Firm's market value to book value. & Le and Bich (2017) \\
\hline \multicolumn{3}{|c|}{ Independent variables } \\
\hline $\begin{array}{l}\text { Overall Leverage } \\
(L E V)\end{array}$ & Ratio of total debt to total assets & $\begin{array}{l}\text { Chen (2004), Chava and } \\
\text { Roberts (2008) }\end{array}$ \\
\hline $\begin{array}{l}\text { Long-Term } \\
\text { Leverage (LTLev) }\end{array}$ & Ratio of long-term debt to total assets & Chen (2004) \\
\hline $\begin{array}{l}\text { Short-Term } \\
\text { Leverage (STLev) }\end{array}$ & Ratio of short-term debt to total assets & Vo (2017) \\
\hline \multicolumn{3}{|l|}{ Control variables } \\
\hline Firm size $(S Z)$ & Log of total assets & $\begin{array}{l}\text { Fosu et al. (2016), Qian } \\
\text { and Yeung (2015) }\end{array}$ \\
\hline Firm growth $(G R)$ & The one-year growth rate of sales & $\begin{array}{l}\text { Fosu et al. (2016), Fosu } \\
(2013)\end{array}$ \\
\hline $\begin{array}{l}\text { Assets tangibility } \\
(T A N)\end{array}$ & Ratio of fixed assets to total assets & $\begin{array}{l}\text { Qian and Yeung (2015); } \\
\text { Danso and Adomako } \\
(2014)\end{array}$ \\
\hline Investment $(I N V)$ & $\begin{array}{l}\text { The ratio of capital expenditures to the } \\
\text { start-of-period net property, plant and } \\
\text { equipment. }\end{array}$ & Chava and Roberts (2008) \\
\hline
\end{tabular}


Table 2: Descriptive statistics

\begin{tabular}{lcccccccc}
\hline & Mean & Std. Dev & Min & Max & $25^{\text {th }} \%$ & $50^{\text {th } \%}$ & $75^{\text {th } \%}$ & Obs \\
TQ & 1.70 & 0.87 & 0.89 & 4.17 & 1.11 & 1.37 & 1.93 & 17331 \\
LEV & 0.31 & 0.21 & 0.00 & 0.71 & 0.12 & 0.31 & 0.46 & 19544 \\
LTLev & 0.19 & 0.17 & 0.00 & 0.57 & 0.03 & 0.14 & 0.30 & 19541 \\
STLev & 0.13 & 0.11 & 0.00 & 0.38 & 0.02 & 0.10 & 0.20 & 18574 \\
SZ & 14.77 & 1.60 & 11.89 & 17.81 & 13.57 & 14.74 & 15.89 & 19559 \\
TAN & 0.37 & 0.21 & 0.04 & 0.74 & 0.20 & 0.36 & 0.53 & 19514 \\
NDTS & 0.03 & 0.02 & 0.00 & 0.08 & 0.02 & 0.03 & 0.04 & 19446 \\
GR & 0.20 & 0.33 & -0.36 & 1.04 & 0.01 & 0.16 & 0.34 & 16893 \\
INV & 0.31 & 0.34 & 0.00 & 1.31 & 0.07 & 0.19 & 0.42 & 16472 \\
\hline
\end{tabular}


Table 3: Correlations matrix

\begin{tabular}{lccccccccc}
\hline & TQ & LEV & LTLev & STLev & SZ & TAN & NDTS & GR & INV \\
TQ & 1.00 & & & & & & & & \\
LEV & $-0.39^{*}$ & 1.00 & & & & & & & \\
LTLev & $-0.29^{*}$ & $0.82^{*}$ & 1.00 & & & & & \\
STLev & $-0.30^{*}$ & $0.59^{*}$ & $0.05^{*}$ & 1.00 & & & & \\
SZ & $0.13^{*}$ & $0.14^{*}$ & $0.16^{*}$ & 0.01 & 1.00 & & & & \\
TAN & $-0.20^{*}$ & $0.43^{*}$ & $0.49^{*}$ & $0.07^{*}$ & $0.13^{*}$ & 1.00 & & \\
NDTS & $-0.03^{*}$ & $0.17^{*}$ & $0.20^{*}$ & $0.03^{*}$ & -0.01 & $0.46^{*}$ & 1.00 & & \\
GR & $0.13^{*}$ & -0.01 & $0.02^{*}$ & $-0.05^{*}$ & $0.05^{*}$ & $-0.06^{*}$ & $-0.10^{*}$ & 1.00 & \\
INV & $0.21^{*}$ & $-0.06^{*}$ & -0.02 & $-0.08^{*}$ & $0.06^{*}$ & $-0.10^{*}$ & $-0.17^{*}$ & $0.31^{*}$ & 1.00 \\
\hline
\end{tabular}

This table presents the correlation matrix for the data. The sample and variable definitions are as described in Table 1. ${ }^{*}$ indicates significance at $1 \%$ or better 
Table 4: Regression results for the full sample period - Dependent variable $=$ TQ

\begin{tabular}{|c|c|c|c|c|c|c|c|c|c|c|c|c|}
\hline & (1) & (2) & (3) & (4) & (5) & (6) & (7) & (8) & (9) & (10) & (11) & (12) \\
\hline & OLS & OLS & FE & $\mathrm{FE}$ & OLS & OLS & $\mathrm{FE}$ & FE & OLS & OLS & $\mathrm{FE}$ & FE \\
\hline LEV & $\begin{array}{c}-1.592^{* * *} \\
(0.068)\end{array}$ & $\begin{array}{c}-1.657^{* * *} \\
(0.070)\end{array}$ & $\begin{array}{c}-0.993^{* * *} \\
(0.064)\end{array}$ & $\begin{array}{c}-1.018^{* * *} \\
(0.075)\end{array}$ & & & & & & & & \\
\hline LTLev & & & & & $\begin{array}{c}-1.557^{* * *} \\
(0.078)\end{array}$ & $\begin{array}{c}-1.640^{\text {**** }} \\
(0.086)\end{array}$ & $\begin{array}{c}-0.821^{\text {*** }} \\
(0.063)\end{array}$ & $\begin{array}{c}-0.818^{* * *} \\
(0.070)\end{array}$ & & & & \\
\hline STLev & & & & & & & & & $\begin{array}{c}-2.141^{\text {*** }} \\
(0.116)\end{array}$ & $\begin{array}{c}-2.020^{* * *} \\
(0.107)\end{array}$ & $\begin{array}{c}-0.803^{* * *} \\
(0.089)\end{array}$ & $\begin{array}{c}-0.747^{* * *} \\
(0.097)\end{array}$ \\
\hline SZ & & $\begin{array}{c}0.113^{* * *} \\
(0.010)\end{array}$ & & $\begin{array}{c}-0.057^{* *} \\
(0.023)\end{array}$ & & $\begin{array}{c}0.112^{* * *} \\
(0.010)\end{array}$ & & $\begin{array}{c}-0.074^{* * *} \\
(0.024)\end{array}$ & & $\begin{array}{c}0.088^{* * *} \\
(0.010)\end{array}$ & & $\begin{array}{c}-0.099^{* * *} \\
(0.024)\end{array}$ \\
\hline TAN & & $\begin{array}{c}-0.385^{* * *} \\
(0.071)\end{array}$ & & $\begin{array}{c}0.072 \\
(0.081)\end{array}$ & & $\begin{array}{c}-0.462^{* * *} \\
(0.076)\end{array}$ & & $\begin{array}{c}0.008 \\
(0.085)\end{array}$ & & $\begin{array}{c}-1.020^{* * *} \\
(0.076)\end{array}$ & & $\begin{array}{c}-0.195^{* *} \\
(0.083)\end{array}$ \\
\hline NDTS & & $\begin{array}{c}4.929^{* * *} \\
(0.697)\end{array}$ & & $\begin{array}{c}1.135 \\
(0.707)\end{array}$ & & $\begin{array}{c}5.060^{* * *} \\
(0.720)\end{array}$ & & $\begin{array}{c}0.652 \\
(0.713)\end{array}$ & & $\begin{array}{c}4.992^{* * *} \\
(0.749)\end{array}$ & & $\begin{array}{c}0.937 \\
(0.733)\end{array}$ \\
\hline GR & & $\begin{array}{c}0.127^{* * *} \\
(0.023)\end{array}$ & & $\begin{array}{c}0.097^{* * *} \\
(0.016)\end{array}$ & & $\begin{array}{c}0.138^{* * *} \\
(0.023)\end{array}$ & & $\begin{array}{c}0.107^{* * *} \\
(0.017)\end{array}$ & & $\begin{array}{c}0.106^{* * *} \\
(0.025)\end{array}$ & & $\begin{array}{c}0.101^{* * *} \\
(0.017)\end{array}$ \\
\hline IN V & & $\begin{array}{c}0.357^{* * *} \\
(0.027)\end{array}$ & & $\begin{array}{c}0.217^{* * *} \\
(0.022)\end{array}$ & & $\begin{array}{c}0.394^{* * *} \\
(0.028)\end{array}$ & & $\begin{array}{c}0.236^{* * *} \\
(0.022)\end{array}$ & & $\begin{array}{c}0.354^{* * *} \\
(0.029)\end{array}$ & & $\begin{array}{c}0.224^{* * *} \\
(0.022)\end{array}$ \\
\hline _cons & $\begin{array}{c}2.849^{* * *} \\
(0.066)\end{array}$ & $\begin{array}{c}0.796^{\text {*** }} \\
(0.148)\end{array}$ & $\begin{array}{l}1.776^{* * *} \\
(0.023)\end{array}$ & $\begin{array}{c}2.558^{* * *} \\
(0.350)\end{array}$ & $\begin{array}{c}2.570^{* * *} \\
(0.080)\end{array}$ & $\begin{array}{c}0.673^{* * *} \\
(0.157)\end{array}$ & $\begin{array}{l}1.584^{* * *} \\
(0.014)\end{array}$ & $\begin{array}{l}2.650^{* * *} \\
(0.369)\end{array}$ & $\begin{array}{l}2.422^{* * *} \\
(0.083)\end{array}$ & $\begin{array}{l}1.150^{* * *} \\
(0.158)\end{array}$ & $\begin{array}{l}1.591^{* * *} \\
(0.019)\end{array}$ & $\begin{array}{c}3.102^{* * *} \\
(0.369)\end{array}$ \\
\hline$N$ & 17317 & 14903 & 17317 & 14903 & 17314 & 14902 & 17314 & 14902 & 16633 & 14389 & 16633 & 14389 \\
\hline r2 & 0.236 & 0.331 & 0.272 & 0.311 & 0.175 & 0.274 & 0.255 & 0.296 & 0.159 & 0.268 & 0.254 & 0.292 \\
\hline N_clust & 2310 & 2264 & 2310 & 2264 & 2310 & 2264 & 2310 & 2264 & 2296 & 2247 & 2296 & 2247 \\
\hline
\end{tabular}

This table presents the OLS and FE estimation results for the entire sample period. Standard errors robust to heteroscedasticity and clustering within firm are given in parentheses. The sample and variable definitions are as described in Table $1 . *$ Indicates significance at 10\%; ** Indicates significance at $5 \% ; * \star *$ Indicates significance at $1 \%$. 


\begin{tabular}{|c|c|c|c|}
\hline & TQ & TQ & TQ \\
\hline LEV & $\begin{array}{c}-0.798^{* * *} \\
(0.278)\end{array}$ & & \\
\hline LTlev & & $\begin{array}{c}-0.906^{* *} \\
(0.359)\end{array}$ & \\
\hline STlev & & & $\begin{array}{c}-1.471^{* *} \\
(0.700)\end{array}$ \\
\hline SZ & $\begin{array}{l}-0.058 \\
(0.061)\end{array}$ & $\begin{array}{l}-0.057 \\
(0.065)\end{array}$ & $\begin{array}{l}-0.083 \\
(0.064)\end{array}$ \\
\hline TAN & $\begin{array}{c}2.481^{* * *} \\
(0.425)\end{array}$ & $\begin{array}{c}2.728^{* * * *} \\
(0.462)\end{array}$ & $\begin{array}{c}1.852^{* * *} \\
(0.457)\end{array}$ \\
\hline NDTS & $\begin{array}{l}-0.977 \\
(3.423)\end{array}$ & $\begin{array}{l}-1.562 \\
(3.603)\end{array}$ & $\begin{array}{l}-0.011 \\
(3.781)\end{array}$ \\
\hline GR & $\begin{array}{c}-0.595^{* * *} \\
(0.124)\end{array}$ & $\begin{array}{c}-0.619^{* * * *} \\
(0.131)\end{array}$ & $\begin{array}{c}-0.596^{* * * *} \\
(0.128)\end{array}$ \\
\hline INV & $\begin{array}{c}1.403^{* * *} \\
(0.254)\end{array}$ & $\begin{array}{c}1.552^{* * *} \\
(0.254)\end{array}$ & $\begin{array}{c}1.305^{* * *} \\
(0.269)\end{array}$ \\
\hline No. of firms & 1829 & 1829 & 1701 \\
\hline K-P WF Stats & 3.981 & 4.731 & 3.300 \\
\hline K-P LM stats & 59.055 & 66.686 & 50.662 \\
\hline H.J stats & 49.041 & 47.958 & 45.013 \\
\hline
\end{tabular}

Standard errors in parentheses. All variable definitions are as described in Table 1. * Indicates significance at 10\%; ** Indicates significance at $5 \% ; * \star *$ Indicates significance at $1 \%$. 
Table 6: Regression results for the full sample period - Dependent variable $=$ ROA

\begin{tabular}{|c|c|c|c|c|c|c|c|c|c|c|c|c|}
\hline & $\begin{array}{c}(1) \\
\text { OIS }\end{array}$ & $\begin{array}{c}(2) \\
\text { OIS }\end{array}$ & $\begin{array}{l}\text { (3) } \\
\mathrm{FE}\end{array}$ & $\begin{array}{l}(4) \\
\mathrm{FE}\end{array}$ & $\begin{array}{c}\text { (5) } \\
\text { OIS }\end{array}$ & $\begin{array}{c}(6) \\
\text { OIS }\end{array}$ & $\begin{array}{l}\text { (7) } \\
\mathrm{FE}\end{array}$ & $\begin{array}{l}(8) \\
\mathrm{FE}\end{array}$ & $\begin{array}{c}\text { (9) } \\
\text { OIS }\end{array}$ & $\begin{array}{c}(10) \\
\text { OIS }\end{array}$ & $\begin{array}{l}\text { (11) } \\
\mathrm{FE}\end{array}$ & $\begin{array}{c}\text { (12) } \\
\mathrm{FE}\end{array}$ \\
\hline LEV & $\begin{array}{c}-0.117^{* * *} \\
(0.006)\end{array}$ & $\begin{array}{c}-0.146^{* * *} \\
(0.006)\end{array}$ & $\begin{array}{c}-0.140^{\text {**** }} \\
(0.007)\end{array}$ & $\begin{array}{c}-0.143^{* * *} \\
(0.007)\end{array}$ & & & & & & & & \\
\hline LTLev & & & & & $\begin{array}{l}-0.120^{* * *} \\
(0.007)\end{array}$ & $\begin{array}{l}-0.165^{* * *} \\
(0.007)\end{array}$ & $\begin{array}{l}-0.113^{* * *} \\
(0.007)\end{array}$ & $\begin{array}{l}-0.106^{* * *} \\
(0.008)\end{array}$ & & & & \\
\hline STLev & & & & & & & & & $\begin{array}{l}-0.133^{* * *} \\
(0.010)\end{array}$ & $\begin{array}{l}-0.135^{\text {*** }} \\
(0.009)\end{array}$ & $\begin{array}{l}-0.113^{\text {*** }} \\
(0.010)\end{array}$ & $\begin{array}{l}-0.115^{\text {*** }} \\
(0.010)\end{array}$ \\
\hline SZ & & $\begin{array}{c}0.008^{* * *} \\
(0.001)\end{array}$ & & $\begin{array}{c}-0.006^{* * *} \\
(0.002)\end{array}$ & & $\begin{array}{c}0.008^{* * *} \\
(0.001)\end{array}$ & & $\begin{array}{c}-0.009^{* * *} \\
(0.002)\end{array}$ & & $\begin{array}{c}0.006^{* * *} \\
(0.001)\end{array}$ & & $\begin{array}{c}-0.010^{* * *} \\
(0.002)\end{array}$ \\
\hline TAN & & $\begin{array}{l}-0.005 \\
(0.006)\end{array}$ & & $\begin{array}{c}-0.047^{* * *} \\
(0.008)\end{array}$ & & $\begin{array}{l}-0.003 \\
(0.007)\end{array}$ & & $\begin{array}{c}-0.057^{* * *} \\
(0.009)\end{array}$ & & $\begin{array}{c}-0.063^{* * *} \\
(0.006)\end{array}$ & & $\begin{array}{c}-0.089^{* * *} \\
(0.009)\end{array}$ \\
\hline NDTS & & $\begin{array}{l}1.133^{* * *} \\
(0.066)\end{array}$ & & $\begin{array}{c}0.949^{* * *} \\
(0.079)\end{array}$ & & $\begin{array}{l}1.152^{* * *} \\
(0.067)\end{array}$ & & $\begin{array}{l}0.874^{* * *} \\
(0.081)\end{array}$ & & $\begin{array}{l}1.136^{* * *} \\
(0.071)\end{array}$ & & $\begin{array}{c}0.918^{* * *} \\
(0.086)\end{array}$ \\
\hline GR & & $\begin{array}{c}0.048^{* * *} \\
(0.002)\end{array}$ & & $\begin{array}{c}0.043^{* * *} \\
(0.002)\end{array}$ & & $\begin{array}{c}0.049^{* * *} \\
(0.002)\end{array}$ & & $\begin{array}{l}0.044^{* * *} \\
(0.002)\end{array}$ & & $\begin{array}{c}0.045^{* * *} \\
(0.003)\end{array}$ & & $\begin{array}{c}0.043^{* * *} \\
(0.002)\end{array}$ \\
\hline INV & & $\begin{array}{l}0.025^{* * *} \\
(0.002)\end{array}$ & & $\begin{array}{c}0.011^{* * *} \\
(0.002)\end{array}$ & & $\begin{array}{c}0.029^{* * *} \\
(0.002)\end{array}$ & & $\begin{array}{l}0.013^{* * *} \\
(0.002)\end{array}$ & & $\begin{array}{l}0.026^{* * *} \\
(0.002)\end{array}$ & & $\begin{array}{l}0.011^{* * *} \\
(0.002)\end{array}$ \\
\hline _cons & $\begin{array}{c}0.198^{* * *} \\
(0.004)\end{array}$ & $\begin{array}{c}0.042^{* * *} \\
(0.012)\end{array}$ & $\begin{array}{c}0.144^{* * *} \\
(0.002)\end{array}$ & $\begin{array}{c}0.222^{* * *} \\
(0.031)\end{array}$ & $\begin{array}{c}0.183^{* * *} \\
(0.004)\end{array}$ & $\begin{array}{c}0.008 \\
(0.012)\end{array}$ & $\begin{array}{c}0.116^{\text {*** }} \\
(0.002)\end{array}$ & $\begin{array}{c}0.241^{* * *} \\
(0.030)\end{array}$ & $\begin{array}{l}0.176^{* * *} \\
(0.004)\end{array}$ & $\begin{array}{c}0.066^{* * *} \\
(0.013)\end{array}$ & $\begin{array}{l}0.119^{* * *} \\
(0.002)\end{array}$ & $\begin{array}{c}0.278^{* * *} \\
(0.031)\end{array}$ \\
\hline$N$ & 19181 & 16109 & 19181 & 16109 & 19178 & 16108 & 19178 & 16108 & 18279 & 15479 & 18279 & 15479 \\
\hline r2 & 0.128 & 0.272 & 0.122 & 0.213 & 0.098 & 0.243 & 0.087 & 0.178 & 0.069 & 0.189 & 0.067 & 0.166 \\
\hline N_clust & 2384 & 2330 & 2384 & 2330 & 2384 & 2330 & 2384 & 2330 & 2368 & 2310 & 2368 & 2310 \\
\hline
\end{tabular}

Standard errors in parentheses. All variable definitions are as described in Table $1 . *$ Indicates significance at $10 \% ; * \star$ Indicates significance at $5 \% ; * \star *$ Indicates significance at $1 \%$. 
Table 7: Regression results for the determinants of firm performance: smaller vs. larger firms

\begin{tabular}{|c|c|c|c|c|c|c|}
\hline & \multicolumn{3}{|c|}{ Smaller firms } & \multicolumn{3}{|c|}{ Larger firms } \\
\hline & (1) & $(2)$ & (3) & (4) & $(5)$ & (6) \\
\hline & FE & FE & $\mathrm{FE}$ & $\mathrm{FE}$ & $\mathrm{FE}$ & FE \\
\hline LEV & $\begin{array}{c}-0.724^{* * * *} \\
(0.148)\end{array}$ & & & $\begin{array}{c}-1.334^{* * * *} \\
(0.164)\end{array}$ & & \\
\hline LTLev & & $\begin{array}{c}-0.506^{* * *} \\
(0.170)\end{array}$ & & & $\begin{array}{c}-1.108^{\text {*** }} \\
(0.144)\end{array}$ & \\
\hline STLev & & & $\begin{array}{c}-0.488^{* * *} \\
(0.162)\end{array}$ & & & $\begin{array}{c}-0.830^{* * *} \\
(0.210)\end{array}$ \\
\hline SZ & $\begin{array}{l}-0.111^{*} \\
(0.059)\end{array}$ & $\begin{array}{c}-0.128^{* *} \\
(0.059)\end{array}$ & $\begin{array}{c}-0.140^{* *} \\
(0.060)\end{array}$ & $\begin{array}{l}-0.016 \\
(0.045)\end{array}$ & $\begin{array}{l}-0.042 \\
(0.045)\end{array}$ & $\begin{array}{l}-0.080^{*} \\
(0.047)\end{array}$ \\
\hline TAN & $\begin{array}{l}0.313^{*} \\
(0.173)\end{array}$ & $\begin{array}{c}0.184 \\
(0.167)\end{array}$ & $\begin{array}{c}0.142 \\
(0.163)\end{array}$ & $\begin{array}{l}-0.045 \\
(0.146)\end{array}$ & $\begin{array}{l}-0.077 \\
(0.153)\end{array}$ & $\begin{array}{c}-0.388^{* *} \\
(0.156)\end{array}$ \\
\hline NDTS & $\begin{array}{c}-3.270^{* *} \\
(1.635)\end{array}$ & $\begin{array}{l}-3.223^{*} \\
(1.654)\end{array}$ & $\begin{array}{c}-3.642^{* *} \\
(1.820)\end{array}$ & $\begin{array}{c}1.169 \\
(1.353)\end{array}$ & $\begin{array}{c}0.498 \\
(1.401)\end{array}$ & $\begin{array}{c}0.668 \\
(1.500)\end{array}$ \\
\hline GR & $\begin{array}{c}0.027 \\
(0.033)\end{array}$ & $\begin{array}{c}0.033 \\
(0.034)\end{array}$ & $\begin{array}{c}0.040 \\
(0.036)\end{array}$ & $\begin{array}{c}0.120^{* * *} \\
(0.031)\end{array}$ & $\begin{array}{c}0.140^{* * *} \\
(0.031)\end{array}$ & $\begin{array}{c}0.125^{* * *} \\
(0.034)\end{array}$ \\
\hline INV & $\begin{array}{l}0.107^{* *} \\
(0.045)\end{array}$ & $\begin{array}{l}0.111^{* *} \\
(0.046)\end{array}$ & $\begin{array}{c}0.128^{* * *} \\
(0.048)\end{array}$ & $\begin{array}{c}0.296^{* * *} \\
(0.040)\end{array}$ & $\begin{array}{c}0.317^{* * *} \\
(0.039)\end{array}$ & $\begin{array}{c}0.295^{* * *} \\
(0.041)\end{array}$ \\
\hline _cons & $\begin{array}{c}2.027^{* *} \\
(0.805)\end{array}$ & $\begin{array}{l}2.092^{* *} \\
(0.811)\end{array}$ & $\begin{array}{c}2.191^{* * * *} \\
(0.815)\end{array}$ & $\begin{array}{c}2.401^{* * *} \\
(0.712)\end{array}$ & $\begin{array}{c}2.608^{* * * *} \\
(0.733)\end{array}$ & $\begin{array}{c}3.195^{* * *} \\
(0.758)\end{array}$ \\
\hline$N$ & 2893 & 2893 & 2728 & 4436 & 4435 & 4352 \\
\hline r2 & 0.289 & 0.279 & 0.276 & 0.404 & 0.384 & 0.364 \\
\hline N_clust & 744 & 744 & 726 & 738 & 738 & 736 \\
\hline
\end{tabular}


Table 8: Regression results for the determinants of firm performance: the role of the crisis

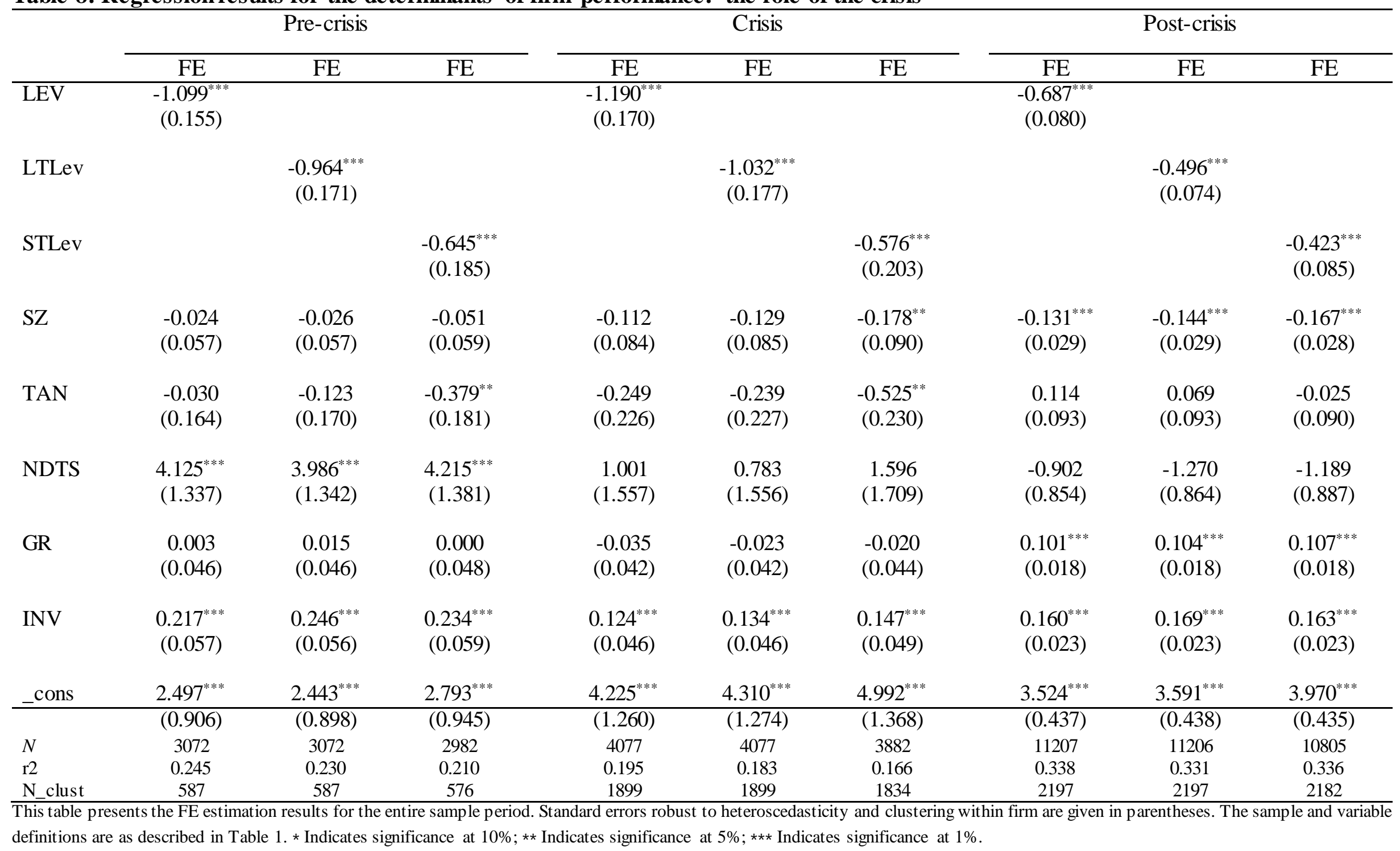

